\title{
Optimization of $\beta$-carotene solubility in pressurized hot water using a dynamic method and factorial methodology
}

\author{
N. Ebrahimi, A. Haghighi Asl*, P. Mottahedin \\ Extraction Research Group, Faculty of Chemical, Gas and Petroleum Engineering, Semnan University, Semnan, \\ Iran
}

Received, February 20, 2018; Revised May 28, 2019

In this experimental investigation, the solubility of $\beta$-carotene in pressurized hot water was measured at temperatures in the range of $(70-130){ }^{\circ} \mathrm{C}$ and the pressure of 20 bar by using a dynamic method. The influence of different variables, including temperature and flow rate in the range of $(0.15-0.64) \mathrm{ml} / \mathrm{min}$, on the solubility of $\beta$ carotene was investigated. Furthermore, the optimization of these parameters was done through the experimental design by using factorial methodology. The results of the experiments showed that the temperature was the main parameter affecting the solubility of $\beta$-carotene in pressurized hot water. The best conditions for solubility of $\beta$-carotene in pressurized hot water were the temperature of $85{ }^{\circ} \mathrm{C}$ and a flow rate of $0.64 \mathrm{ml} / \mathrm{min}$. $\beta$-carotene's solubility data in pressurized hot water were correlated with the dielectric constant values of the solvent mixture.

Keywords: Solubility, $\beta$-carotene, Pressurized hot water, Factorial methodology, Correlation, Dielectric constant

\section{INTRODUCTION}

$\beta$-carotene is a main subgroup of carotenoids. It can be found in vegetables, for example, pumpkin [1]. Many of the carotenoid compounds can be extracted from deep color vegetables and fruits because they are rich sources of phenolic compounds, including flavonoids and carotenoids [2-5]. On the other hand, for the food engineering design applications, it is important to have fundamental physicochemical data, such as solute solubility in the solvents. Solubility data are used for optimization of extraction processes. $\beta$-carotene solubility in solvents such as ethane and supercritical $\mathrm{CO}_{2}$ is measured [6-8]. Many carotenoids are sensitive to environmental factors such as light, heat, and oxygen; therefore, such measurements are challenging [9].

In recent years, due to the growing interest in subcritical fluid technology, a number of novel approaches have been proposed to measure the solubility of organic components in pressurized hot water [10-20]. These methods can be basically classified into static and dynamic methods [21]. To our knowledge, pressurized hot water, defined as water between $100{ }^{\circ} \mathrm{C}$ and $374{ }^{\circ} \mathrm{C}$, is an effective solvent for both polar and non-polar compounds [22]. Water is a solvent with tunable polarity. When the temperature increases, the polarity of water decreases. Therefore, the solubility of non-polar organics increases [23].

In the static method, an extra amount of solute and a certain amount of solvent are loaded into an equilibration cell. After the equilibrium is achieved, the sample solution is provided for analysis [21]. In the dynamic method, the solvent flows through an equilibrium solubility cell continuously. The cell contains an excess amount of the solute under the experimental temperature and pressure conditions. After the system reaches the equilibrium conditions the sample solution flows through a valve or restrictor for analysis. Miller et al. [24] used the dynamic method to measure the solubility of hydrophobic organics in pressurized hot water. Also, Zhang et al. [25] used the same method to investigate the solubility of carbohydrates in pressurized hot water. Takebayashi et al. [26] used the dynamic method for measuring the solubility of terephthalic acid in pressurized hot water whose temperature was in the range of $75-275^{\circ} \mathrm{C}$. Karasek et al. [27] used the dynamic method to measure the solubility of solid polycyclic aromatic hydrocarbons in pressurized hot water at temperatures ranging from $313 \mathrm{~K}$ to the melting point. Modeling the solubility of polycyclic aromatic hydrocarbons can be useful for predicting the solubility data in pressurized hot water [28]. The experimental procedure of the dynamic method is easy and quick. Also, it is difficult to measure the solubility of sensitive compounds above the boiling point of water using a static apparatus [9].

The objective of this research is to measure the solubility of $\beta$-carotene in pressurized hot water at temperatures ranging from 70 to $130{ }^{\circ} \mathrm{C}$ and a constant pressure of $20 \mathrm{bar}$. Since the solubility of $\beta$-carotene is low in water at room temperature, the

* To whom all correspondence should be sent:

E-mail: ahaghighi@semnan.ac.ir 
$N$. Ebrahimi et al.: Optimization of $\beta$-carotene solubility in pressurized hot water using a dynamic method ... pressurized hot water is used to enhance its solubility in water. The dynamic method has been used for these measurements. In this experimental investigation, the effect of temperature and flow rate on the solubility of $\beta$-carotene has been reported. Additionally, the mentioned variables were optimized through the design of experiments using factorial methodology. Also, $\beta$-carotene solubility data were correlated with the dielectric constants of the solvent.

\section{EXPERIMENTAL}

\section{Materials}

$\beta$-Carotene $(\geq 93 \%)$ was from Sigma-Aldrich. In this work, HPLC-grade water was utilized for all experiments. HPLC-grade ethyl acetate, acetonitrile, and methanol were purchased from DAEJUNG.

\section{Apparatus and methods}

The system used for measuring the solubility of $\beta$-carotene was based on a modification of the system used by Karasek et al. [29].

Solubility measurements were conducted with a dynamic flow type system [30]. This apparatus is schematically shown in Fig. 1. The experimental system had an HPLC pump (SY-8100 series, BFRL Co., Germany) which can work with very low flow rates. The inlet of pipelines was equipped with a burette to check the flow rate of the pump. The solubility cell was located in an oven. The role of this oven was to control the temperature (up to 250 $\pm 1{ }^{\circ} \mathrm{C}$ ) by using a PID controller. The sole solvent, HPLC grade water, was maintained in the ultrasonic cleaner system for $20 \mathrm{~min}$ at a temperature of $60{ }^{\circ} \mathrm{C}$. After that, a 5-L Pyrex feed tank was filled with water and purged with nitrogen for $1 \mathrm{~h}$ to eliminate dissolved $\mathrm{O}_{2}$. In each experiment, the cell was filled with $0.1 \mathrm{~g}$ of $\beta$ carotene. To avoid the particles' flow, two stainless steel filter, two fabric filters, and a soft metal filter were used at both cell sides.

In all experiments, the pressure of 20 bar was selected because the liquid water was needed at the extraction temperatures. When the outlet valve was closed, the HPLC pump was turned on to obtain the specified pressure. Subsequently, the pump was turned off and by using the oven the system reached the specified temperature. At this time, the outlet valve was opened and the HPLC pump started to work with the specified rate in which the pressure was kept constant at 20 bar. At the end of the pipeline, a fused-silica capillary tube (i.d. $75 \mu \mathrm{m}$ ) was located inside the oven. Due to the usage of the capillary tube, the pressure was kept at the desired capillary tube in the oven, to minimize the measurement errors. When each run finished, the samples are analyzed using HPLC.

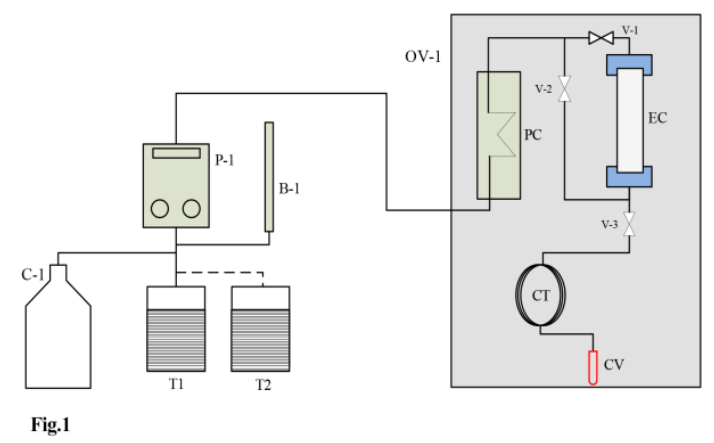

Fig. 1. Schematic diagram of the solubility measurement system, B-1: burette, C-1: nitrogen cylinder, EC: cell, PC: preheating coil, OV-1: oven, P-1: HPLC pump, T1: water tank, T2: solvent tank, v-1: cell inlet valve, v-3: cell outlet valve, v-2: bypass valve, CT: capillary tube, CV: sample collection vial.

The experimental system was equipped with an HPLC pump (SY-8100 series, BFRL Co., Germany) which can work with very low flow rates. The inlet of pipelines was connected with a burette to check the flow rate of the pump. The solubility cell was located in an oven. The role of this oven was to control the temperature (up to 250 $\pm 1{ }^{\circ} \mathrm{C}$ ) by using a PID controller. The sole solvent, HPLC-grade water, was maintained in a ultrasonic cleaner system for $20 \mathrm{~min}$ at a temperature of $60^{\circ} \mathrm{C}$. After that, the 5-L Pyrex feed tank was filled with water and purged with nitrogen for $1 \mathrm{~h}$ to eliminate dissolved $\mathrm{O}_{2}$. In each experiment, the cell was filled with $0.1 \mathrm{~g}$ of $\beta$-carotene. To avoid the particles' flow, two stainless steel filters, two fabric filters, and a soft metal filter were used at both cell sides.

In all experiments, the pressure of 20 bar was selected because liquid water was needed at the extraction temperatures. When the outlet valve was closed, the HPLC pump was turned on to obtain the specified pressure. Subsequently, the pump was turned off and by using the oven the system reached the specified temperature. At this time, the outlet valve was opened and the HPLC pump started to work with the specified rate in which the pressure was kept constant at 20 bar. At the end of the pipeline, a fused-silica capillary tube (i.d. $75 \mu \mathrm{m}$ ) was located inside the oven. Due to the usage of the capillary tube, the pressure was kept at the desired value. Samples were collected after the capillary tube. When each run finished, the samples were analyzed by HPLC.

\section{$\beta$-Carotene quantification analysis}

The calibration of HPLC was conducted by 
$N$. Ebrahimi et al.: Optimization of $\beta$-carotene solubility in pressurized hot water using a dynamic method ... solutions containing a $\beta$-carotene stock solution in acetonitrile. The concentrations of $\beta$-carotene were 200, 100, 50, 25 and $12.5 \mathrm{ppm}$. As can be seen in Fig. 2, the calibration curve was regressed with a linear function.

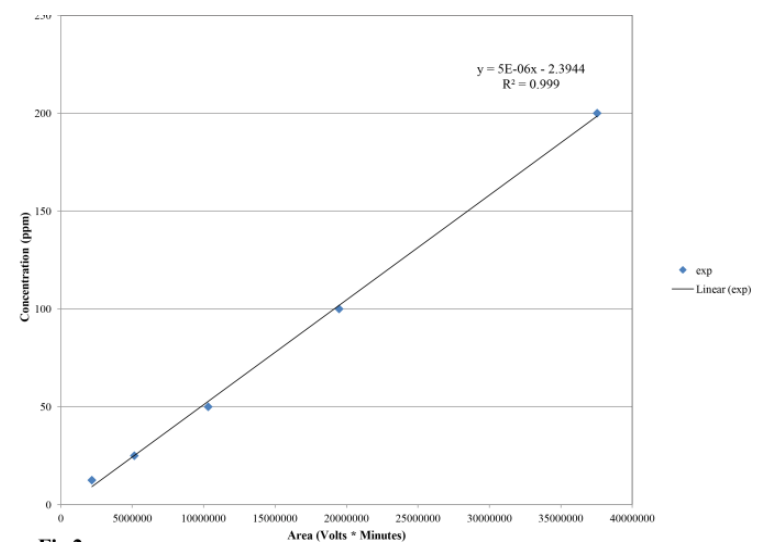

Fig. 2. Calibration curve for $\beta$-carotene

\section{Factorial design}

The experimental design of the factors affecting the solubility, including temperature and pressurized hot water flow rate, was investigated under full factorial design. The factorial design was done to reduce the cost, to design optimization, and to avoid time-consuming analysis methods [31]. The constants of the factorial equations were obtained by MINITAB 16. Each statistical analysis was done two times for each solubility process to ensure their reproducibility. Table 1 indicates the factors, ranges, and levels of independent variables in the factorial design.

Table 1. Ranges of the independent variables in the factorial design

\begin{tabular}{llcc}
\hline Factor & Type & Levels & Values \\
\hline $\mathrm{T}\left({ }^{\circ} \mathrm{C}\right)$ & Fixed & 3 & $70,85,130$ \\
$\mathrm{Q}(\mathrm{ml} / \mathrm{min})$ & Fixed & 3 & $0.15,0.42,0.64$ \\
\hline
\end{tabular}

\section{Dielectric constant model}

Table 2. Dielectric constant values for temperatures between $0{ }^{\circ} \mathrm{C}$ and $200{ }^{\circ} \mathrm{C}$ and $0 \%$ and $20 \%$ (v/v) ethanol in water solutions [32].

\begin{tabular}{cccc}
\hline $\mathrm{T}$ & \multicolumn{3}{c}{ Ethanol \% (v/v) } \\
\cline { 2 - 4 }$\left({ }^{\circ} \mathrm{C}\right)$ & 0 & 5 & 20 \\
\hline 0 & 80.37 & 77.43 & 68.66 \\
50 & 72.54 & 69.82 & 61.69 \\
100 & 65.47 & 62.95 & 55.43 \\
110 & 64.15 & 61.66 & 54.26 \\
120 & 62.84 & 60.40 & 53.11 \\
130 & 61.57 & 59.16 & 51.99 \\
140 & 60.32 & 57.95 & 50.88 \\
150 & 59.10 & 56.76 & 49.81 \\
160 & 57.90 & 55.60 & 48.75 \\
170 & 56.72 & 54.46 & 47.72 \\
180 & 55.57 & 53.34 & 46.71
\end{tabular}

$\begin{array}{llll}190 & 54.44 & 52.25 & 45.72 \\ 200 & 53.34 & 51.18 & 44.75\end{array}$

Table 2 [32] illustrates the dielectric constant values for different temperatures and different volume percentages of ethanol in water.

$\beta$-Carotene solubility data from this work and a previous work [30] can be correlated with the dielectric constant values in table 2 .

\section{RESULTS AND DISCUSSION HPLC analysis}

The HPLC analysis of $\beta$-carotene was conducted using a reversed-phase HPLC system (Knauer Company, Germany). The HPLC chromatograms of $\beta$-carotene are shown in Fig. 3. The solvents used were (A) acetonitrile:water (9:1 v/v) and (B) ethyl acetate. The solvent gradient utilized was developed as follows: $0-40 \%$ solvent B $(0-20 \mathrm{~min})$, 40-60\% solvent B (20-25 min), 60-100\% solvent B (25-25.1 min), $100 \%$ solvent B (25.1-35 $\mathrm{min})$, and $100-0 \%$ solvent $\mathrm{B}(35-35.1 \mathrm{~min})$ at a flow rate of $1.0 \mathrm{ml} \mathrm{min}{ }^{-1}$ [1]. The temperature of the column was maintained at $20^{\circ} \mathrm{C}$. The injection volume was $20 \mu \mathrm{l}$.
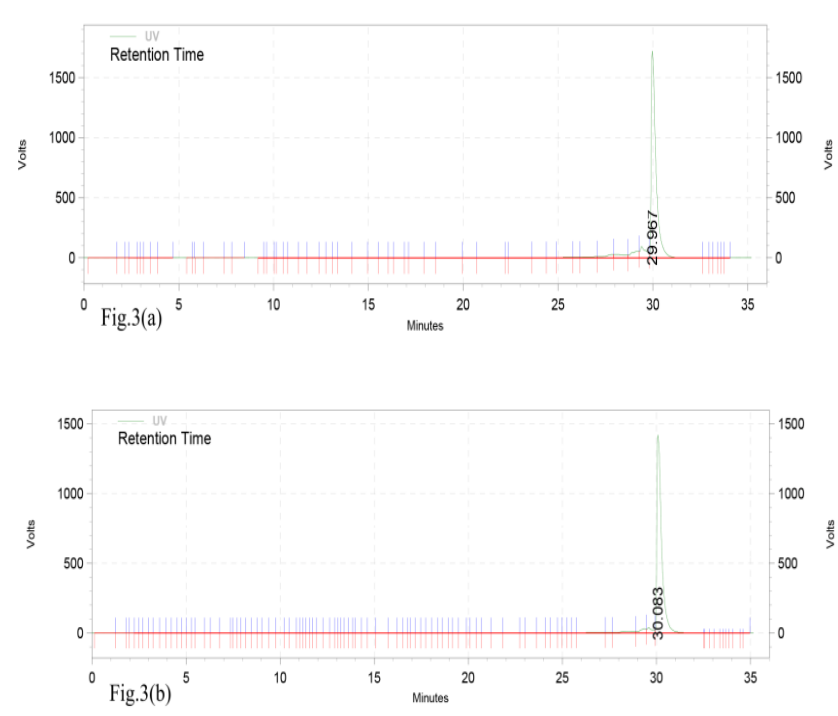

Fig. 3. HPLC chromatogram of (a) $\beta$-carotene standard and (b) $\beta$-carotene (obtained at $85^{\circ} \mathrm{C}$ )

\section{Factorial analysis}

The obtained experimental solubilities of $\beta$ carotene in pressurized hot water are presented in Table 3. Table 4 shows the importance of each parameter by considering the $\mathrm{P}$ value and contribution term. The most significant variables affecting the yield of $\beta$-carotene solubility were the linear terms of temperature and flow rate and the interaction term of temperature and flow rate $(\mathrm{P}<0.05)$. R-squared $=99.84 \%$ and R-squared $(\operatorname{adj})$ $=99.69 \%$ indicate that the experimental data are in good agreement with the predicted values. 
N. Ebrahimi et al.: Optimization of $\beta$-carotene solubility in pressurized hot water using a dynamic method ... Table 3. The result of the two factors-three levels

\begin{tabular}{cccc}
\hline Exp. & $\mathrm{T}\left({ }^{\circ} \mathrm{C}\right)$ & $\mathrm{Q}(\mathrm{ml} / \mathrm{min})$ & $\mathrm{C}(\mathrm{ppm})$ \\
\hline 1 & 70 & 0.15 & 71.456 \\
2 & 70 & 0.42 & 87.587 \\
3 & 70 & 0.64 & 105.586 \\
4 & 85 & 0.15 & 85.242 \\
5 & 85 & 0.42 & 130.004 \\
6 & 85 & 0.64 & 173.338 \\
7 & 130 & 0.15 & 6.654 \\
8 & 130 & 0.42 & 9.653 \\
9 & 130 & 0.64 & 10.878 \\
10 & 70 & 0.15 & 65.023 \\
11 & 70 & 0.42 & 89.618 \\
12 & 70 & 0.64 & 110.989 \\
13 & 85 & 0.15 & 88.949 \\
14 & 85 & 0.42 & 137.006 \\
15 & 85 & 0.64 & 180.188 \\
16 & 130 & 0.15 & 5.992 \\
17 & 130 & 0.42 & 8.154 \\
18 & 130 & 0.64 & 10.622 \\
\hline
\end{tabular}

Table 4. $\mathrm{P}$ value and contribution term

\begin{tabular}{ccc}
\hline Source & P value & Contribution \\
\hline $\mathrm{T}$ & 0.000 & 0.83 \\
$\mathrm{Q}$ & 0.000 & 0.11 \\
$\mathrm{~T}^{*} \mathrm{Q}$ & 0.000 & 0.06 \\
\hline
\end{tabular}

\section{Effect of independent variables on the solubility}

The effect of operating parameters (temperature and pressurized hot water flow rate) on the solubility of $\beta$-carotene was investigated. The plots of the response (beta carotene solubility) against the independent variables are shown in Figs. 4 and 5.

As shown in Fig.4 (a) at a constant water flow rate, an increase in temperature leads to an increase in the solubility of $\beta$-carotene up to the temperature of $85^{\circ} \mathrm{C}$. After this temperature, due to the thermal degradation of $\beta$-carotene, the solubility decreases. Thermal degradation of $\beta$-carotene is visible by the change in the color of the solution and decrease of the area under the chromatogram peak. According to Fig.4 (b) at a constant temperature, increasing the flow rate of water enhances the solubility $\beta$ carotene with a mild slope. It is because of higher superficial velocity and so higher coefficient of mass transfer. Fig.5 (a, b) shows the contour plot of the $\beta$-carotene solubility $v s$. T, Q.

\section{Dielectric constant model}

Fig. 6 shows the solubility data for $\beta$-carotene in pressurized hot water solutions against the dielectric constant values of the solvent mixture.
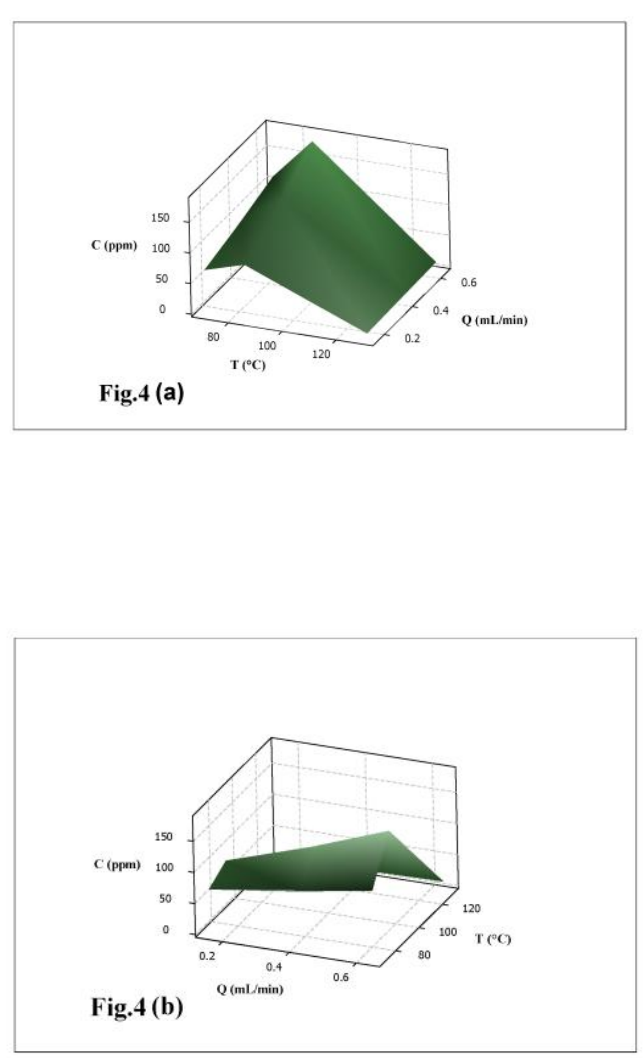

Fig. 4. (a, b) Factorial plots of $\beta$-carotene solubility as a function of temperature and flow rate at a pressure of $20 \mathrm{bar}$.
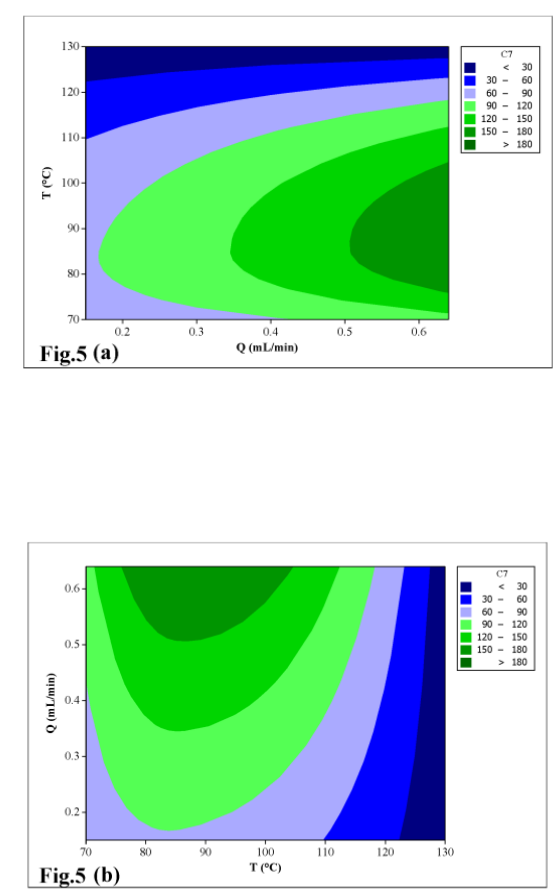

Fig. 5. (a, b) Contour plots of $\beta$-carotene solubility 
$N$. Ebrahimi et al.: Optimization of $\beta$-carotene solubility in pressurized hot water using a dynamic method ... vs. T, Q

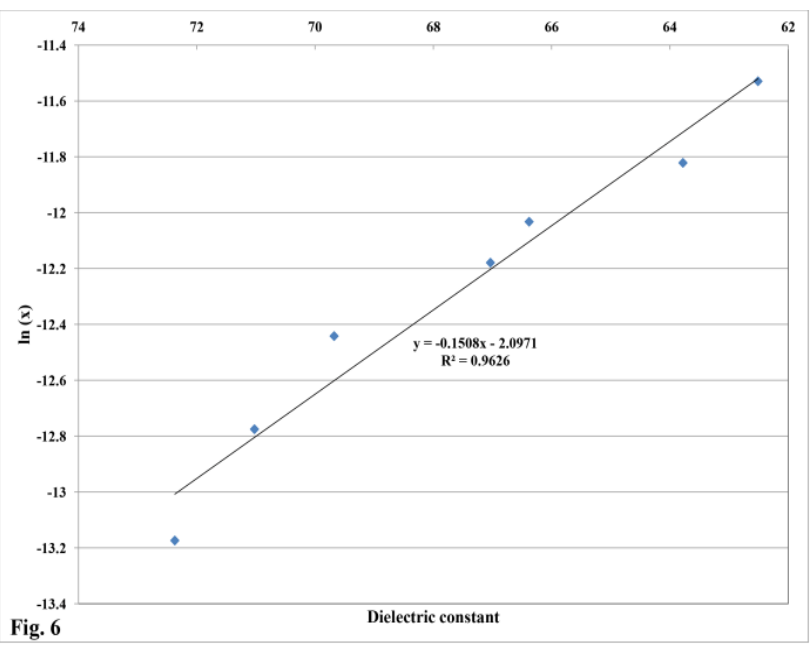

Fig. 6. Solubility of $\beta$-carotene in pressurized hot water solutions vs. dielectric constant values.

As can be seen in Fig. 6, the following equation stands for the solubility of $\beta$-carotene in pressurized hot water solution as a function of dielectric constant:

$$
\ln \mathrm{x}=\mathrm{Ad}+\mathrm{B}
$$

where $\mathrm{x}$ is the solubility and $\mathrm{d}$ is the dielectric constant. The constants $\mathrm{A}$ and $\mathrm{B}$ for $\beta$-carotene are as follows: $\mathrm{A}=-0.1508$ and $\mathrm{B}=-2.0971$.

The validity and goodness of the model were checked by the coefficient of determination $\left(\mathrm{R}^{2}\right)$ value. $R^{2}=0.9626$ indicates acceptable model validation.

\section{CONCLUSIONS}

The experimental solubility measurement of $\beta$ carotene in pressurized hot water was carried out in the temperature range of $(70-130){ }^{\circ} \mathrm{C}$ and water flow rate of $0.15-0.64 \mathrm{ml} / \mathrm{min}$. The dynamic approach was used to investigate the solubility of $\beta$ carotene in pressurized hot water. The operating conditions were optimized by using factorial methodology. The optimal conditions for solubility of $\beta$-carotene were the temperature of $85^{\circ} \mathrm{C}$ and the flow rate of $0.64 \mathrm{ml} / \mathrm{min}$. Also, the experimental solubility data of $\beta$-carotene were correlated with the dielectric constants of pressurized hot water solutions with $\mathrm{R}^{2}=0.9626$.

\section{REFERENCES}

1. S. Norshazila, J. Irwandi, R. Othman, H. H. Yumi Zuhanis, Int. Food Research J., 19, 531 (2012).

2. J. Y. Qian, D. Liu, A. G. Huang, Food Chem., 87, 283 (2004).

3. A. Sass-Kiss, J. Kiss, P. Milotay, M. M. Kerek, M. Toth-Markus, Food Research Int., 38, 1023 (2005).

4. A. Trappey, H. A. Bawadi, R. R. Bansode, J. N. Losso, Food Chem., 91, 665 (2005).
5. E. Cieślik, A. Gręda, W. Adamus, Food Chem., 94 135 (2006).

6. R.L. Mendes, B.P. Nobre, J.P. Coelho, A.F. Palavra, J. Supercrit. Fluids, 16, 99, (1999)

7. B.N. Hansen, A.H. Harvey, J.A.P. Coelho, A.M.F Palavra, and Th.J. Bruno, J. Chem. Eng. Data, 46, 1054, (2001).

8. K. Sakaki, J. Chem. Eng. Data, 37, 249 (1992).

9. K. Srinivas, J. W. King, L. R. Howard, \& J. K. Monrad, J. Food Eng., 100, 208 (2010).

10. W.H. Teoh, R. Mammucari, S.A.B. Vieira de Melo, N.R. Foster, Ind. Eng. Chem. Res., 52, 5806 (2013).

11. E. Yabalak, Ö. Görmez, B. Gözmen, A. M. Gizir, Int. J. Ind. Chem., 6, 23 (2015).

12. P. Karásek, B. Hohnová, J. Planeta, and M. Roth, J. Chem. Eng. Data, 55, 2866 (2010).

13. P. Karásek, B. Hohnová, J. Planeta, L. Št'avíková, M. Roth, Chemosphere, 90, 2035 (2013).

14. A. G. Carr, R. Mammucari, N. R. Foster, Ind. Eng. Chem. Res. 49, 3403 (2010).

15. A. G. Carr, R. Mammucari, N. R. Foster, Ind. Eng. Chem. Res. 49, 9385 (2010).

16. P. Karásek, J. Planeta, M. Roth, J. Chem. Eng. Data, 53, 160 (2008).

17. P. Karásek, J. Planeta, M. Roth, J. Chem. Eng. Data, 53, 816 (2008).

18. K. Srinivas, J. W. King, L. R. Howard, J. K. Monrad, J. Chem. Eng. Data, 55, 3101 (2010).

19. P. Huang, R. Yang, T. Qiu, X. Fan, J. Supercrit. Fluids, 81, 221 (2013).

20. W.H. Teoh, S.A.B. Vieira de Melo, R. Mammucari, N. R. Foster, Ind. Eng. Chem. Res., 53, 10238 (2014).

21. K. Bei, C. Zhang, J. Wang, K. Li, J. Lyu, J. Zhao, J. Chen, I. M. Chou, Z. Pan, Fluid Phase Equil., 425, 93 (2016).

22. P. Mottahedin, A. Haghighi Asl, M. Khajenoori, $J$. Food Proces. Preserv., 41, e13095 (2017).

23. A. G. Carr, R. Mammucari, N. R. Foster, Chem. Eng. J., 172, 1 (2011).

24. D. J. Miller, S. B. Hawthorne, J. Chem. Eng. Data, 45, 78 (2000).

25. D. Zhang, F. Montanés, K. Srinivas, T. Fornari, E. Ibánez, J. W. King, Ind. Eng. Chem. Research, 49, 6691 (2010).

26. Y. Takebayashi, K. Sue, S. Yoda, Y. Hakuta, T. Furuya, J. Chem. Eng. Data, 57, 1810 (2012).

27. P. Karásek, J. Planeta, M. Roth, J. Chromat. A, 1140, 195 (2007).

28. P. Mottahedin, A. Haghighi Asl, M. N. Lotfollahi, J. Solution Chem., 46, 2191 (2017).

29. P. Karásek, J. Planeta, M. Roth, J. Chem. Eng. Data, 51, 616 (2006).

30. P. Mottahedin, A. Haghighi Asl, \& M. N. Lotfollahi, J. Mol. Liquids, 237, 257 (2017).

31. O. Anurukvorakun, Mahidol University J. Pharma. Sci, 40, 7 (2013).

32. A. G. Carr, A. Branch, R. Mammucari, N. R. Foster, J. Supercrit. Fluids, 55, 37 (2010). 